M

олекулярные маркеры риска развития злокачественных новообразований кожи у больных псориазом, получающих фототерапию

\author{
М.Б. Жилова, А.А. Кубанов
}

ФГБУ «Государственный научный центр дерматовенерологии и косметологии» Минздрава России 107076, Москва, ул. Короленко, д. 3, стр. 6

Цель. Изучение возможных молекулярно-генетических маркеров повышенного риска развития злокачественной меланомы кожи на основании оценки нуклеотидных замен генов эксцизионной системы репарации ДНК у больных псориазом, получающих фрототерапию.

Материал и методы. Исследовали биообразцы крови у 47 больных псориазом, 24 больных злокачественной меланомой кожи и 20 здоровых лиц. Использованы следующие методы: клинический, молекулярно-биологические (выделение ДНК, амплификация, полимеразная цепная реакция, секвенирование).

Результаты. Определены молекулярные маркеры повышенного риска развития злокачественной меланомы кожи у больных псориазом: генотип СС гена XPD в позиции 35931 ( $p=0,00001)$; генотип ТС гена XPF в позиции 27945 ( $p=0,0067)$. Установлен молекулярный маркер повышенного риска развития злокачественной меланомы кожи у здоровых лиц: генотип СС гена XPD в позиции 35931 ( $p=0,0042)$.

Ключевые слова: фототерапия, гены эксцизионной системы репарации ДНК (XPD, XPC, XPF, ERCC1, XRCC1), злокачественная меланома кожи, секвенирование.

Контактная информация: zhilova@cnikvi.ru. Вестник дерматологии и венерологии 2014; (6): 62—68.

\title{
Wolecular markers of the risk of development of skin cancer in psoriasis patients receiving a phototherapy
}

\author{
M.B. Zhilova, A.A. Kubanov
}

State Research Center of Dermatovenereology and Cosmetology, Ministry of Healthcare of the Russian Federation Korolenko str., 3, bldg 6, Moscow, 107076, Russia

Goal. To study potential molecular and genetic markers of an increased risk of development of malignant skin melanomas on the basis of the assessment of nucleotide replacements of genes in the excision system of DNA repair in psoriasis patients receiving a phototherapy.

Materials and methods. Biological blood samples taken from 47 psoriasis patients, 24 patients with malignant skin melanomas and 20 healthy subjects. The following methods were used in the study: clinical, molecular and biological (DNA extraction, amplification, PCR, sequencing).

Results. The study revealed molecular markers of an increased risk of development of malignant skin melanomas in psoriasis patients: CC genotype of the XPD gene at the 35931 locus $(p=0.00001)$; TC genotype of the XPF gene at the 27945 locus $(p=0.0067)$.

It also revealed a molecular marker of an increased risk of development of malignant skin melanomas in healthy people: CC genotype of the XPD gene at the 35931 locus ( $p=0.0042)$.

Key words: phototherapy, genes of the excision system of DNA repair (XPD, XPC, XPF, ERCC1, XRCC1), malignant skin melanoma, sequencing.

Corresponding author: zhilova@cnikvi.ru. Vestnik Dermatologii i Venerologii 2014; 6: 62—68. 
В лечении распространенных и тяжелых фрорм псориаза широко используются методы фрототерапии, включающие ПУВА-терапию и УФВ-311. К преимуществам методов УФ-терапии относят высокую эффективность, хорошую переносимость, отсутствие резистентности при курсовом применении, экономическую доступность.

Однако в долгосрочной перспективе фрактором, ограничивающим применение УФ-излучения у больных псориазом, является потенциальная канцерогенность.

Длительное воздействие экзогенных мутагенных факторов, включающих УФ-излучение, - наиболее частая причина развития злокачественных новообразований кожи. По данным литературы, у больных псориазом отмечена взаимосвязь длительного применения ПУВА-терапии и повышения риска развития злокачественной меланомы кожи [1-6, 8, 9]. Развитие случаев меланомы кожи отмечено у больных псориазом, получавших как низкие, так и высокие кумулятивные дозы ПУВА-терапии (324, 2800 Дж/см²) [7]. Данный факт предполагает помимо мутагенного действия УФ-излучения на кожу наличие других предикторов канцерогенеза. Установлено, что побочные эфрфекты УФ-облучения (ожоги) также повышают риск развития меланомы кожи $[10,11]$. Поскольку УФ-индуцированные ожоги кожи развиваются за счет излучения в УФВ-диапазоне (280-320 нм), предполагается, что УФВ-излучение наряду с УФА-спектром может выступать в качестве потенциального фрактора риска развития меланомы кожи [12].

Одним из важнейших механизмов защиты кожи от злокачественной трансформации, вызванной УФизлучением, является система репарации повреждений ДНК. УФ-индуцированные повреждения ДНК устраняются системой нуклеотидной эксцизионной репарации (NER) и кодируются генами семейства XP [13]. Предполагается, что уменьшенная способность $\mathrm{K}$ репарации ДНК является предрасполагающим фактором риска развития рака кожи [14, 15]. У больных пигментной ксеродермой с врожденными дефектами системы эксцизионной репарации ДНК более чем в 1000 раз повышается риск развития УФ-индуцированного рака кожи по сравнению с общей популяцией $[16,17]$.

По данным современных исследований в области медицины и генетики, в последнее десятилетие были получены многочисленные данные, свидетельствующие о том, что полиморфизмы генов эксцизионной репарации ДНК способны модулировать предрасположенность к злокачественным новообразованиям, включая злокачественную меланому кожи [18-21]. Предполагается, что фенотипические и генотипические корреляции системы эксцизионной репарации ДНК модулируются генетическими полиморфизмами NER генов. Кроме того, каждый вариант NER аллели или генотипа может частично влиять на фенотип и та- ким образом на генетическую восприимчивость к развитию злокачественного новообразования [22].

По данным литературы, к наиболее значимым генам, полиморфизмы которых ассоциированы с предрасположенностью к развитию злокачественных новообразований кожи, относят: 16-й экзон гена $X P C, 9-и ̆$

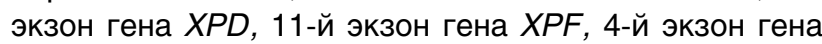

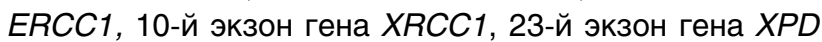
[23-31].

Цель исследования: изучение возможных молекулярно-генетических маркеров повышенного риска развития злокачественной меланомы кожи на основании анализа распределения нуклеотидных замен генов эксцизионной системы репарации ДНК у больных псориазом, получающих фототерапию.

\section{Материал и методы}

В исследование вошли 47 больных со среднетяжелыми и тяжелыми формами псориаза, получающих методы фототерапии, 24 больных со злокачественной меланомой кожи и 20 здоровых лиц. Все обследуемые лица относились к европеоидной расе. С целью изучения молекулярно-генетических маркеров повышенного риска развития злокачественной меланомы кожи были изучены и сопоставлены частоты распределения нуклеотидных замен функционально значимых участков генов эксцизионной системы репарации ДНК (16-го экзона гена ХРС в позициях 32724, 33343, $32828,33350,32864$; 9-го экзона гена $X P D$ в позиции 6491 ; 23-го экзона гена $X P D$ в позиции 35931 ; 11-го экзона гена XPF в позициях 28095, 27945; 4-го экзона гена ERCC1 в позиции 19007; 10-го экзона гена XRCC1 В позиции 28152) у всех обследуемых лиц. В качестве биоматериала для исследования использовались биообразцы цельной крови.

Статистическая обработка результатов исследования проводилась с использованием пакета программ Statistica 8 (Statsoft Inc., США), программного обеспечения MS Excel (Microsoft). Описательная статистика количественных признаков представлена в виде среднего \pm стандартное отклонение, качественных признаков - абсолютными и относительными частотами. Сравнение групп по качественным признакам осуществляли с использованием критерия Стьюдента $(p<0,05)$, поправки Бонферрони $(p<0,017)$.

\section{Клиническая характеристика больных обследу- емых групп}

В обследуемую группу было включено 34 мужчины и 13 женщин. Средний возраст пациентов составлял 48,1 \pm 10,1 года. Все пациенты имели вульгарную форму псориаза. Значение индекса PASI составляло от 10,3 до 35. Средняя продолжительность заболевания $22,5 \pm 13,0$ года. По фототипам кожи больные псориазом распределились следующим образом: 1-й фототип кожи имели 4,2\% $(n=2)$ больных, 2-й $-46,8 \%$ 
( $n=22), 3-\breve{и}-46,8 \%(n=22), 4-\breve{n}-2,1 \%(n=1)$. Высокой степени солнечной инсоляции подвергались $23,4 \%(n=11)$ больных, средней - 48,9\% $(n=23)$, низкой $-27,7 \%(n=13)$. Солнечные ожоги отмечали в анамнезе 27 больных псориазом.

Среди больных псориазом было 13 больных, впервые получавших фототерапию (ПУВА-терапия или УФВ-311), и 34 больных, получавших многокурсовое лечение методами фототерапии. 30 больным проводился курс ПУВА-терапии, 12 больных получали УФБ-311. Число курсов фототерапии варьировало от 3 до 15. Все больные псориазом на момент осмотра не имели признаков злокачественных новообразований кожи и семейных случаев меланомы кожи.

В исследование были включены 24 больных со злокачественной меланомой кожи, имевших различные стадии заболевания (у 5 больных - T2aN0M0, у 6 больных - T3bNOM0, у 5 больных - T3bN1M0, у 3 больных - T3aN2M0, у 5 больных - T3bN3M0). Bce пациенты находились на лечении в ФГБУ «МНИОИ им. П.А. Герцена» Минздрава России, диагноз был подтвержден результатами гистологического исследования. Семейных случаев меланомы кожи у наблюдавшихся пациентов выявлено не было. По формам заболевания отмечалось следующее распределение: поверхностно-распространяющаяся форма - у 14, узловатая - у 3, лентиго-меланома - у 7. Локализация первичной злокачественной опухоли была следующая: кожа лица - у 20,8\% ( $n=5)$, кожа шеи - у $25 \%$ $(n=6)$, кожа предплечий - у 29,2\% $(n=7)$, кожа туловища - у 8,3\% $(n=2)$, кожа голеней - у 16,7\% $(n=4)$. Все опухоли были пигментообразующими.

Среди обследуемых больных со злокачественной меланомой кожи было 15 мужчин и 9 женщин. Средний возраст пациентов составил 51,5 $\pm 12,3$ года. Преобладающими возрастными группами дебюта заболевания были группы 50-59 лет - 6 пациентов и 60-69 лет - 9 пациентов.

По фототипам кожи больные распределились следующим образом: 1-й фототип кожи был у 2 (8,3\%) больных, 2-й тип - у 12 (54,1\%), 3-й тип — у 9 (37,5\%), 4-й тип кожи не встречался. Интенсивность солнечной инсоляции была высокой у 16,6\% $(n=4)$ больных, средней - у 58,3\% $(n=14)$ и низкой - у $25 \%(n=6)$. Солнечные ожоги в течение жизни имели $50 \%(n=12)$ больных.

В группу сравнения включено 20 добровольцев, не имевших признаков злокачественных новообразований кожи и семейных случаев меланомы кожи. В том числе 14 мужчин и 6 женщин в возрасте от 26 до 60 лет (средний возраст 45,3 + 12,3 года). 1-й фототип кожи был у 5\% ( $n=1), 2-и ̆-$ у $55 \%(n=11)$, 3-й - у $40 \%$

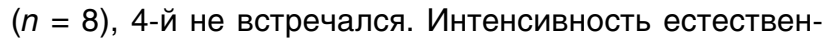
ной инсоляции была высокой у $25 \%(n=5)$, средней у $55 \%(n=11)$, низкой - у $20 \%(n=4)$. Солнечные ожоги имели 12 здоровых лиц.
Достоверно значимых различий в обследуемых группах по возрасту, полу, основным типам кожи, интенсивности солнечной инсоляции не отмечалось ( $p>0,05, t$-критерий Стьюдента).

\section{Методы молекулярно-генетических исследо- ваний}

Молекулярно-генетические исследования проводились методом секвенирования на аппарате APPLIED BIOSYSTEMS 3730XL DNA Analyzer (США).

Этапы исследования нуклеотидных последовательностей выбранных генов эксцизионной системы репарации ДНК (XPD, XPC, XPF, ERCC1, XRCC1) для поиска мутаций или нуклеотидных замен включали: выделение ДНК из биообразцов; амплификацию ДНК выбранных генов для последующего секвенирования нуклеотидной последовательности; детекцию и визуализацию продуктов амплификации ДНК выбранных генов; осаждение продуктов амплификации ДНК выбранных генов; проведение сиквенсовой ПЦР; осаждение продуктов сиквенсовой ПЦР; проведение реакции секвенирования.

Для проведения аплификации фрагментов генов эксцизионной системы репарации ДНК были подобраны праймеры, характеристика которых представлена в табл. 1.

\section{Результаты}

Результаты изучения частоты распределения нуклеотидных замен генов эксцизионной системы репарации ДНК у больных псориазом

В результате проведенных молекулярно-генетических исследований методом секвенирования у больных псориазом в функционально значимом участке 23-го экзона гена $X P D$ были обнаружены нуклеотидные замены в позиции 35931 AC/AA/CC: у 7 (14,89\%) больных псориазом - полиморфизм 35931 А > С, соответствующий гомозиготному генотипу СС (или двум аллелям C); у $21(44,68 \%)$ пациента - гомозиготный генотип AА и у 21 (44,68\%) - гетерозиготный генотип AC.

Нуклеотидных замен гена XPD в позиции 6491 (GG/AA) выявлено не было.

При секвенировании функционально значимого участка гена XPC у больных псориазом были обнаружены нуклеотидные замены в позициях 32724 (CC/ AA), 32864 (TT/CC), 32828 (CC/GC), 33343 (TT/TA/AA) и 33350 (AA/AG/GG):

у $13(27,66 \%)$ больных - замена нуклеотидов в позиции $32724 \mathrm{C}>\mathrm{A}$, соответствующая гомозиготному генотипу АA (или двум аллелям A); у остальных пациентов регистрировался гомозиготный генотип CC (34/47; 72,34\%);

у 1 (2,13\%) пациента - замена нуклеотидов в позиции 32864 Т > C, соответствующая гетерозиготному генотипу СС; у остальных пациентов регистрировался гомозиготный генотип ТТ (46/47; 97,87\%); 
Таблица 1 Праймеры для проведения амплификации фррагментов генов эксцизионной системы репарации ДНК

\begin{tabular}{|c|c|c|c|}
\hline Ген & Последовательность праймеров & Температура отжига, ${ }^{\circ} \mathrm{C}$ & Размер амплифицируемого продукта, п. н. \\
\hline$X P D$ & $\begin{array}{l}\text { F: TCACCCTGCAGCACTTCGTT } \\
\text { R: CTGTCTCTATCCATCTGCTC }\end{array}$ & 64 & 673 \\
\hline$X P C$ & $\begin{array}{l}\text { F: TCTCCTTAGTACAGAGAGCTT } \\
\text { R: CTGATTACTAACCCTCGCCT }\end{array}$ & 60 & 1014 \\
\hline$X P F$ & $\begin{array}{l}\text { F: GAGAGTTCTTCCCCAGTGAC } \\
\text { R: CCTATGATGTCTGGCAAGGA }\end{array}$ & 62 & 841 \\
\hline$X P D$, ex23 & $\begin{array}{l}\text { F: TCAAACATCCTGTCCCTACTGGCCAT } \\
\text { R: CTGCGATTAAAGGCTGTGGACGTGAC }\end{array}$ & 67 & 344 \\
\hline ERCC1 & $\begin{array}{l}\text { F: TCATCCCTATTGATGGCTTCTGCCC } \\
\text { R: GACCATGCCCAGAGGCTTCTCATAG }\end{array}$ & 69 & 252 \\
\hline$X R C C 1$ & $\begin{array}{l}\text { F: CCCAAGTACAGCCAGGTCCTAG } \\
\text { R: AGTCTGACTCCCCTCCAGATTC }\end{array}$ & 58 & 171 \\
\hline
\end{tabular}

- у 4 (8,51\%) больных - замена нуклеотидов в позиции $32828 \mathrm{C}>\mathrm{G}$, соответствующая гетерозиготному генотипу GC (аллели C и G); у остальных пациентов регистрировался гомозиготный генотип CC - у $43(91,49 \%)$;

в позиции $33343 \mathrm{~T}>\mathrm{A}$, соответствующей гомозиготному генотипу $A A$, замен нуклеотидов обнаружено не было; у 6 (12,77\%) пациентов регистрировался гетерозитотный генотип ТА, у остальных гомозиготный генотип ТТ - у 42 (89,36\%);

- у 1 (2,13\%) больного - замена нуклеотида в позиции $33350 \mathrm{~A}>\mathrm{G}$, соответствующая гомозиготному генотипу GG (два аллеля G); у 41(87,23\%) пациентов регистрировался гомозиготный генотип $A A$, у 5 $(10,64 \%)$ - генотип AG.

При секвенировании функционально значимого участка гена XPF в позиции 27945 Т > С у $14(26,66 \%)$ больных псориазом обнаружена замена - гомозиготный генотип СС. У остальных пациентов регистрировался гомозиготный генотип ТТ - у 25 (53,19\%) из 47 и гетерозиготный генотип ТС - у 9 (19,15\%) из 47. Нуклеотидные замены в позиции 28095G > А выявлялись со следующей частотой: гомозиготный генотип AA у 2 (4,46\%), гетерозиготный генотип $A G-$ у 2 (4,46\%), гомозиготный генотип GG - у 43 (97,87\%).

При секвенировании функционально значимого участка гена $E R C C 1$ у 23 больных была обнаружена нуклеотидная замена в позиции 19007 Т > С, гомозиготный генотип ТТ - у 23 (48,94\%); у остальных пациентов регистрировались: гетерозиготный генотип ТС - у 18 (38,3\%) и гомозиготный генотип СС у $6(12,77 \%)$.

При секвенировании функционально значимого участка гена XRCC1 у 16 больных регистрировалась нуклеотидная замена в позиции 28152 A > C, гомозиготный генотип AА (34,0\%); у остальных пациентов выявлен генотип AC (30/47; 63,8\%) и генотип CC (1/47; 2,13\%).
Результаты изучения частоты распределения нуклеотидных замен генов эксцизионной системы репарации ДНК у здоровых лиц

В результате молекулярно-генетических исследований, проведенных у здоровых лиц, нуклеотидная замена гена XPD в позиции 6491 (GG/AA), соответствующая генотипу AA функционально значимого участка гена $X P D$, обнаружена у 2 (10\%) добровольцев, у остальных регистрировался генотип GG (90\%).

Нуклеотидная замена в позиции $35931 \mathrm{~A}>\mathrm{C}$ гена $X P D$, соответствующая гомозиготному генотипу CC (или двум аллелям С), была обнаружена у 4 (20,0\%) человек, у остальных регистрировались гомозиготный генотип AА - у 7 (35,0\%) человек и гетерозиготный генотип $A C$ - у 9 (45,0\%).

У 7 (35,0\%) добровольцев обнаружена замена нуклеотидов гена XPC в позиции 32724 (генотип АA); у остальных регистрировался гомозиготный генотип CC - у $13(65,0 \%)$ из 20.

У 5 добровольцев была обнаружена замена нуклеотидов гена $X P C$ в позиции 33343, гетерозиготный генотип ТА (25,0\%); у остальных регистрировался гомозиготный генотип ТТ - у 15 (75,0\%). У 7 добровольцев обнаружена замена нуклеотидов гена $X P C$ в позиции 33350 - у 6 (30\%) - гетерозиготный генотип AG; у $1(5 \%)$ - гомозиготный генотип GG; у остальных 13 (65\%) человек был зарегистрирован гомозиготный генотип AA.

При секвенировании функционально значимого участка гена XPF в позиции 27945 у большинства здоровых добровольцев $(65,0 \%)$ был обнаружен генотип ТТ, у 6 (30\%) человек - гетерозиготный генотип ТС и у $1(5 \%)$ - гомозиготный генотип СС.

У 1 (5\%) добровольца была обнаружена замена нуклеотидов в позиции 28095 (гетерозиготный генотип AG; у остальных регистрировался гомозиготный генотип GG - у 19 (95\%) из 20. 
При секвенировании функционально значимого участка гена $E R C C 1$ у 3 здоровых добровольцев была обнаружена нуклеотидная замена в позиции 19007 T > C, гомозиготный генотип СС - у 3 (15,0\%) из 20; гетерозиготный генотип ТС встречался у 9 (45\%), у остальных регистрировался гомозиготный генотип TT - у 8 (40\%)

При секвенировании функционально значимого участка гена XRCC1 у 4 (20\%) человек регистрировалась нуклеотидная замена в позиции 28152 A > C, соответствующая гомозиготному генотипу СC, у остальных выявлен гомозиготный генотип АA - у 7 (35\%) и гетерозиготный генотип AC - у 9 (45\%).

Результаты изучения частоты распределения нуклеотидных замен генов эксцизионной системы репарации ДНК у больных злокачественной меланомой кожи

В результате проведенных молекулярно-генетических исследований у 24 больных злокачественной меланомой кожи в функционально значимом участке 23-го экзона гена XPD замена нуклеотидов $35931 \mathrm{~A}>\mathrm{C}$, соответствующая гомозиготному генотипу СС (или двум аллелям С), была обнаружена у 15 (62,5\%) больных; у остальных пациентов генотипы в данной позиции распределялись следующим образом: гомозиготный генотип AA - у 3 (12,5\%) пациентов и гетерозиготный генотип AC - у 7 (29,17\%). Нуклеотидных замен гена XPD в позиции 6491 (GG/AA) выявлено не было.

При секвенировании функционально значимого участка гена XPC у больных псориазом были обнаружены нуклеотидные замены в позициях 32724 (СС/ AA), 32864 (TT/CC), 32828 (CC/GC), 33343 (TT/TA/AA) и 33350 (AA/AG/GG):

у $7(29,17 \%)$ больных - замена нуклеотидов в позиции $32724 \mathrm{C}>\mathrm{A}$, соответствующая гомозиготному генотипу $A A$ (или двум аллелям A); у остальных пациентов регистрировался гомозиготный генотип СС - у $17(70,83 \%)$ из 24;

у 4 (16,67\%) больных - замена нуклеотидов в позиции 32828 C > G, соответствующая гетерозиготному генотипу GC (аллели C и G); у остальных пациентов регистрировался гомозиготный генотип СС - у $20(83,33 \%)$ из 24.

В позиции 33343 Т > А нуклеотидная замена, соответствующая гомозиготному генотипу ТА, была выявлена у 6 (25\%) больных; у остальных пациентов регистрировался гомозиготный генотип ТТ -у 18 (75\%) из 24.

В позиции 32864 Т > С у пациентов регистрировался гомозиготный генотип ТТ - у 22 (91,67\%) из 24 и гомозиготный генотип СС - у 2 (8,33\%) из 24.

В позиции 33350 A > G нуклеотидная замена, соответствующая генотипу AG, установлена у 6 (25\%) больных, у остальных регистрировался гомозиготный генотип AA - у $16(66,67 \%)$ и гомозиготный генотип $\mathrm{GG}-$ y 2 (8,33\%).
При секвенировании функционально значимого участка гена XPF у больных злокачественной меланомой кожи была обнаружена нуклеотидная замена в позиции 27945 (ТT/ТС/СC), соответствующая гетерозиготному генотипу ТС, у 15 (62,5\%) пациентов, у $1(4,17 \%)$ - гомозиготный генотип СС, у остальных больных регистрировался гомозиготный генотип ТТ у $8(33,33 \%)$ из 24. Нуклеотидная замена в позиции $28095 \mathrm{G}>\mathrm{A}$, соответствующая гетерозиготному генотипу AG, была выявлена у 3 (12,5\%) больных, генотип AA - у 1 (4,17\%), у остальных пациентов регистрировался гомозиготный генотип GG - у 20 (83,33\%).

При секвенировании функционально значимого участка гена XRCC1 у 11 больных была обнаружена нуклеотидная замена в позиции 28152 A > C, гомозиготный генотип СС - у $5(20,83 \%)$ из 24; гетерозиготный генотип AC - у 7 (29,17\%), у остальных пациентов регистрировался гомозиготный генотип АA 12 (50\%) из 24.

При секвенировании функционально значимого участка гена ERCC1 в позиции 19007 T > С у 5 пациентов выявлен гомозиготный генотип СС $(20,83)$, гетерозиготный генотип ТС - у 6 (25\%\%), гомозиготный генотип ТТ - у 13 (54,17\%).

Было проведено статистическое сравнение частот встречаемости между группами малой выборки с учетом поправки Бонферрони $(p<0,017)$. Установлено статистически значимое преобладание частоты встречаемости нуклеотидной замены АС в позиции 28132 гена XRCC1 у больных псориазом (63,83\%), по сравнению с больными меланомой кожи $(29,17 \% ; p<0,017)$.

Отмечено достоверно значимое преобладание генотипа CC гена XRCC1 в позиции 28152 у больных злокачественной меланомой кожи $(20,83 \%)$ и здоровых лиц (20\%) по сравнению с больными псориазом $(2,13 \% ; p<0,017)$.

Отмечено достоверно значимое увеличение частоты встречаемости генотипа CC гена XPD в позиции 35931 у больных меланомой кожи $(62,5)$ по сравнению с больными псориазом (14,89\%) и здоровыми лицами $(20 \% ; p<0,017)$.

Установлено достоверно значимое преобладание генотипа ТС гена XPF в позиции 27945 у больных меланомой кожи по сравнению с больными псориазом $(19,15 \%)$ и здоровыми лицами $(30 \% ; p<0,017)$.

Также отмечено достоверно значимое различие частоты встречаемости генотипа СC гена XPF в позиции 27945 у больных псориазом $(27,66 \%)$ по сравнению с больными меланомой кожи $(4,17 \%)$ и здоровыми лицами (5\%; $p<0,017 ;$ табл. 2).

\section{Обсуждение}

Оценка безопасности назначения многокурсовых фототерапевтических методов лечения чрезвычайно актуальна, так как методы фототерапии в лечении псориаза широко распространены. 
Таблица 2

Частота (в \%) распределения генотипов генов системы эксцизионной репарации ДНК у больных псориазом, злокачественной меланомой кожи и здоровых лиц

\begin{tabular}{|c|c|c|c|c|c|c|}
\hline & $\begin{array}{c}\text { Здоровые (3) } \\
n=20\end{array}$ & $\begin{array}{c}\text { Псориаз (П) } \\
n=47\end{array}$ & $\begin{array}{c}\text { Меланома (M) } \\
n=24\end{array}$ & $\begin{array}{c}P \\
\text { 3-ח }\end{array}$ & $\begin{array}{c}P \\
3-M\end{array}$ & $\stackrel{P}{\mathrm{M}-\Pi}$ \\
\hline eX10 XRCC1 (28152) AA & 35,00 & 34,04 & 50,00 & 0,9371 & 0,3172 & 0,1919 \\
\hline eX10 XRCC1 (28152) AC & 45,00 & 63,83 & 29,17 & 0,1489 & 0,2717 & 0,0052 \\
\hline eX10 XRCC1 (28152) CC & 20,00 & 2,13 & 20,83 & 0,0099 & 0,9348 & 0,0064 \\
\hline eX4 ERCC1 (19007) TT & 40,00 & 48,94 & 54,10 & 0,4990 & 0,3535 & 0,6902 \\
\hline eX4 ERCC1 (19007) TC & 45,00 & 38,30 & 25,00 & 0,5926 & 0,1634 & 0,2727 \\
\hline eX4 ERCC1 (19007) CC & 15,00 & 12,77 & 20,83 & 0,8270 & 0,6081 & 0,3808 \\
\hline XPD35931 (eX23) AA & 35,00 & 44,68 & 12,50 & 0,4479 & 0,6081 & 0,0054 \\
\hline XPD35931 (eX23) AC & 45,00 & 40,43 & 29,17 & 0,7039 & 0,2717 & 0,3618 \\
\hline XPD35931 (eX23) CC & 20,00 & 14,89 & 62,50 & 0,6138 & 0,0042 & 0,00001 \\
\hline XPD (6491) GG & 90,00 & 100,00 & 100,00 & 0,0277 & 0,1128 & 1,000 \\
\hline XPD (6491) AA & 10,00 & 0,00 & 0,00 & 0,0277 & 0,1128 & 1,000 \\
\hline XPD (6491) AG & 0,00 & 0,00 & 0,00 & 1,000 & 1,000 & 1,000 \\
\hline XPC (32724) CC & 65,00 & 72,34 & 70,83 & 0,5675 & 0,6703 & 0,9295 \\
\hline XPC (32724) AA & 35,00 & 27,66 & 29,17 & 0,5675 & 0,6703 & 0,9295 \\
\hline XPC (33343) TT & 75,00 & 87,23 & 75,00 & 0,9800 & 0,7108 & 0,2035 \\
\hline XPC (33343) TA & 25,00 & 12,77 & 25,00 & 0,0980 & 0,7108 & 0,2035 \\
\hline XPC (33343) AA & 0,00 & 0,00 & 0,00 & 1,000 & 1,000 & 1,000 \\
\hline XPC (32828) CC & 75,00 & 91,49 & 83,33 & 0,0821 & 0,5138 & 0,3212 \\
\hline XPC (32828) GC & 25,00 & 8,51 & 16,67 & 0,0699 & 0,5138 & 0,2859 \\
\hline XPC (33350) AA & 65,00 & 87,23 & 66,67 & 0,0378 & 0,8890 & 0,0453 \\
\hline XPC (33350) AG & 30,00 & 10,64 & 25,00 & 0,0562 & 0,7108 & 0,1254 \\
\hline XPC (33350) GG & 5,00 & 2,13 & 8,33 & 0,5028 & 0,6906 & 0,2239 \\
\hline XPC (32864) TT & 90,00 & 97,87 & 91,67 & 0,1435 & 0,8166 & 0,2239 \\
\hline XPC (32864) CC & 10,00 & 2,13 & 8,33 & 0,1435 & 0,8166 & 0,2239 \\
\hline XPF (28095) GG & 95,00 & 91,49 & 83,33 & 0,5765 & 0,2149 & 0,3212 \\
\hline XPF (28095) AG & 5,0 & 4,26 & 12,50 & 1,000 & 1,000 & 1,000 \\
\hline XPF (28095) AA & 0 & 4,26 & 4,17 & 0,3643 & 0,3658 & 1,000 \\
\hline XPF (27945) TT & 65,00 & 57,40 & 33,33 & 0,3645 & 0,2075 & 0,5768 \\
\hline XPF (27945) TC & 30,00 & 17,20 & 62,5 & 0,3221 & 0,1791 & 0,0067 \\
\hline XPF (27945) CC & 5,00 & 31,91 & 4,20 & 0,0348 & 0,8728 & 0,0165 \\
\hline
\end{tabular}

Примечание. $p<0,017$ с учетом поправки Бонферрони.

Полученные нами результаты, свидетельствующие об ассоциации полиморфизма $\mathrm{A}>\mathrm{C}$ гена $X P D$ в позиции 35931 (XPD/ERCC2 SNP rs13181) с риском развития меланомы кожи, подтверждаются данными метаанализа зарубежных авторов [32]. При этом частота распределения полиморфизмов данного гена имеет существенные различия в разных популяционных группах [33, 34].

Наиболее существенным результатом исследования в российской популяции явилось обнаружение генотипа CC гена XPD в позиции 35931, который достоверно преобладал у больных меланомой кожи по сравнению с больными псориазом и здоровыми лицами, и генотипа ТС гена XPF в позиции 27945, который достоверно чаще встречался у больных меланомой кожи по сравнению с больными псориазом $(p<0,017)$.

Современные молекулярно-генетические технологии позволят разработать диагностические тестсистемы для обследования пациентов, получающих лечение методами фототерапии в медицинских организациях дермато-венерологического профиля с целью выявления предикторов высокого риска развития злокачественных новообразований кожи, в том числе меланомы.

\section{Заключение}

В работе установлены молекулярные предикторы повышенного риска развития злокачественной ме- 
ланомы кожи у больных псориазом: генотип СС гена $X P D$ в позиции $35931(p=0,00001)$, генотип ТС гена XPF в позиции 27945 ( $p=0,0067)$.
Установлен молекулярный предиктор повышенного риска развития злокачественной меланомы кожи у здоровых лиц: генотип СС гена XPD в позиции 35931 $(p=0,0042)$.

\section{Литература}

1. Chen Y.J., Wu C.Y., Chen T.J., et al. The risk of cancer in patients with psoriasis: a population-based cohort study in Taiwan. J Am Acad Dermatol 2011; 65: 84 - 91.

2. Bergner T., Przybilla B. Malignant melanoma in association with phototherapy. Dermatology 1992; 184 (1): 59-61.

3. D. Kemmett, H. Reshad, and H. Baker Nodular malignant melanoma and multiple squamous cell carcinomas in a patient treated by photochemotherapy for psoriasis. Br Med J (Clin Res Ed). 1984; Dec 1, 289 (6457): 1498.

4. Azoury S.C., Lange J.R. Epidemiology, Risk Factors, Prevention, and Early Detection of Melanoma. Surg Clin North Am. 2014 Oct; 94 (5): 945—962.

5. Reichrath J., Reichrath S. Sunlight, vitamin D and malignant melanoma: an update. Adv Exp Med Biol 2014; 810: 390-405.

6. Moan J.E., Baturaite Z., Dahlback A., Porojnicu A.C. Ultraviolet radiation and cutaneous malignant melanoma. Adv Exp Med Biol 2014; 810: 359—74.

7. Marx J.L., Auerbach R., Possick P., Myrow R., Gladstein A.H., Kopf A.W. Malignant melanoma in situ in two patients treated with psoralens and ultraviolet $A$. J Am Acad Dermatol 1983 Dec; 9 (6): 904-11.

8. Alcalay J., Bucan C., Kripke M.L. Cutaneous pigmented melanocytic tumor in a mouse treated with psoralen plus ultraviolet A radiation. Photodermatol Photoimmunol Photomed 1990; 7: 28—31.

9. Aubin F., Donawho C.K., Kripke M.L. Effect of psoralen plus ultraviolet A radiation on in vivo growth of melanoma cells. Cancer Res 1991; 51: 5893—5897.

10. Brenner A.V., Lubin J.H., Calista D., Landi M.T. Instrumental measurements of skin color and skin ultraviolet light sensitivity and risk of cutaneous malignant melanoma: a case-control study in an Italian population. Am J Epidemiol 2002: 156: 353-362.

11. Tabenkin H., Tamir A., Sperber A.D., Shapira M., Shvartzman P. A case-control study of malignant melanoma in Israeli Kibbutzin. Isr Med Assoc J 1999; 1: 154-157.

12. Wang S. O. Setlow R. Berwick M., Polsky D., Marghoob A.A., Kopf A.W., Bart R.S. Ultraviolet A and melanoma: a review. J Am Acad Dermatol 2001 May; 44 (5): 837-46.

13. Sancar A. DNA repair in human. Annu Rev Genet 1995; 29: 69-105.
14. Grossman L., Wei Q. DNA repair and epidemiology of basal cell carcinoma. Clin Chem 1995; 41: 1854-63.

15. Wei Q., Matanoski G.M., Farmer E.R., Hedayati M.A. Grossman L. DNA repair and aging in basal cell carcinoma: a molecular epidemiology study. Proc Natl Acad Sci U S A 1993; 90: 1614_-8.

16. Kraemer K.H. The role of sunlight and DNA repair in melanoma and nonmelanoma skin cancer.The xeroderma pigmentosum paradigm. K.H. Kraemer, M.M. Lee, A.D. Andrews, W.C. Lambert. Arch Dermatol 1994; 130: 1018-1021.

17. Setlow R.B. Evidence that xeroderma pigmentosum cells do not perform the first step in the repair of ultraviolet damage to their DNA. R.B. Setlow, J.D. Regan, J. German et al. Proc Natl Acad Sci USA 1969; 64: 1035-1041.

18. Dybdahl M. Low DNA repair is a risk factor in skin carcinogenesis: a study of basal cell carcinoma in psoriasis patients. M. Dybdahl, G. Frentz, U. Vogel, H. Wallin, B.A. Nexo. Mutat Res 1999; 433: P. 15-22.

19. Winsey S.L. A variant within the DNA repair gene XRCC3 is associated with the development of melanoma skin cancer. S.L. Winsey, N.A. Haldar, H.P. Marsh et al. Cancer Res 2000; 60: 5612 - 5616.

20. Qiao Y. Modulation of repair of ultraviolet damage in the host-cell reactivation assay by polymorphic XPC and XPD/ERCC2 genotypes. Y. Qiao, M.R. Spitz, H. Shen et al. Carcinogenesis 2002: 23: 295-299.

21. Baccarelli A. XPD gene polymorphism and host characteristics in the association with cutaneous malignant melanoma risk / A. Baccarelli, D. Calista, P. Minghetti et al. Br J Cancer 2004; 90: 497-502.

22. Tomescu D. Nucleotide excision repair gene XPD polymorphisms and genetic predisposition to melanoma / D. Tomescu, G. Kavanagh, T. Ha, H. Campbell, D.W. Melton. Carcinogenesis 2001; 22: 403—408.

23. Applebaum K.M. Polymorphisms in nucleotide excision repair genes, arsenic exposure, and nonmelanoma skin cancer in New Hampshire. K.M. Applebaum, M.R. Karagas, D.J. Hunter, P.J. Catalano, S.H. Byler, S. Morris, H.H. Environ Health Perspect 2007; 115 (8): 231-236.

24. Bishop S.C. DNA repair synthesis in human skin exposed to ultraviolet radiation used in PUVA (psoralen and UV-A) therapy for psoriasis. S.C. Bishop. Br J Dermatol 1979; 101 (4): 399—405.
25. Bishop C. DNA Repair Elicited by UVB During PUVA Therapy for Psoriasis. C. Bishop and E. Abel. Arch Dermatol Res 1985; 278: 25-30.

26. Cleaver J.E. A Summary of Mutations in the UV-Sensitive Disorders: Xeroderma Pigmentosum, Cockayne Syndrome, and Trichothiodystrophy. J.E. Cleaver, L.H. Thompson, A.S. Richardson, J.C. States. HUMAN MUTATION 1999; 14: 9-22.

27. Li L. Characterization of molecular defects in Xeroderma pigmentosum group C. L. Li, E.S. Bales, C.A. Peterson, R.J. Legerski. Nat. Genet 1993; 5: 413—417.

28. Povey J.E. et al. DNA repair gene polymorphisms and genetic predisposition to cutaneous melanoma. Carcinogenesis 2007: 28 (5): 1087-1093.

29. Shen H., Xu Y., Qian Y., Yu R., Qin Y., Wang X., Spitz $M$., Wei $Q$. Polymorphisms of the DNA repair gene XRCC1 and risk of cancer in a Chinese population. Int J Cancer 2000; 88: 601—606,

30. Kertat K., Rosdahl I., Sun X.F., Synnerstad I., Zhang $\mathrm{H}$. The GIn/Gln genotype of XPD codon 751 as a genetic marker for melanoma risk and Lys/GIn as an important predictor for melanoma progression: a case control study in the Swedish population. Oncol Rep 2008 Jul; 20 (1): 179—83.

31. Ahmad A., Enzlin J.H., Bhagwat N.R., Wijgers N., Raams A., Appledoorn E., Theil A.F., J Hoeijmakers J.H., Vermeulen W., J Jaspers N.G., Schärer O.D., Niedernhofer L.J. Mislocalization of XPF, ERCC1 nuclease contributes to reduced DNA repair in XP-F patients. PLoS Genet 2010 Mar 5; 6 (3): e1000871.

32. Mocellin S., Verdi D., Nitti D. DNA repair gene polymorphisms and risk of cutaneous melanoma: a systematic review. and meta-analysis. Carcinogenesis 2009; 30 (10): 1735-1743

33. Zhu H.L., Bao J.M., Lin P.X., Li W.X., Zou Z.N., Huang Y.E., Chen Q., Shen H. XPD Lys751GIn and Asp312Asn polymorphisms and susceptibility to skin cancer: a meta-analysis of 17 case-control studies. Asian Pac J Cancer Prev. 2014; 15 (16): 6619-25.

34. Kertat K., Rosdahl I., Sun X.F., Synnerstad I., Zhang $\mathrm{H}$. The genotype of as a genetic marker for melanoma risk and Lys/Gln as an important predictor for melanoma progression: a case control study in the Swedish population. Oncol Rep 2008 Jul; 20 (1): 179—83.

об авторах:

А.А. Кубанов - д.м.Н., профессор, зам. директора по научной работе ФГБУ «ГНЦК» Минздрава России, Москва

М.Б. Жилова — к.м.н., зав. отделением фризиотерапии ФГБУ «ГНЦДК» Минздрава России, Москва

\section{Конфликт интересов}

Авторы заявляют об отсутствии потенциального конфликта интересов, требующего раскрытия в данной статье 